Received: 23-08-2020

Revised: 05-10-2020

Published: 31-10-2020

\title{
MATHEMATIC COMMUNICATION SKILLS IN SENIOR HIGH SCHOOL BASED ON GENDER DIFFERENCES
}

\author{
Harfin Lanya ${ }^{1}$, Moh. Zayyadi ${ }^{2}$, Septi Dariyatul Aini ${ }^{3}$, Haris ${ }^{4}$ \\ ${ }^{1,2,3}$ Pendidikan Matematika, Universitas Madura, Pamekasan \\ ${ }^{1}$ lanya_math@unira.ac.id \\ 2zayyadi@unira.ac.id \\ ${ }^{3}$ septi_math@unira.ac.id
}

\begin{abstract}
Abstrak: Penelitian ini bertujuan untuk mendeskripsikan dan menganalisis komunikasi matematis tertulis siswa SMA pada soal program linear berdasarkan gender. Penelitian ini dilaksanakan di SMAN 3 Pamekasan kelas XI MIPA I. Subjek dalam penelitian ini adalah 2 siswa dari 32 siswa kelas XI MIPA I yang merupakan kelas unggulan matematika yang dipilih secara purposive sampling. Penelitian ini menggunakan penelitian deskriptif dengan pendekatan kualitatif. Instrumen yang digunakan adalah Tes Kemampuan Matematika, Tes Komunikasi matematis tertulis dan Pedoman Wawancara. Data dianalisis secara deskriptif berupa data kualitatif yang diperoleh dari hasil Tes tulis untuk menggambarkan komunikasi matematis tertulis siswa. Hasil penelitian menunjukkan bahwa siswa perempuan lebih dominan dibanding siswa laki-laki pada ranah kognitif dan menyelesaikan masalah matematika secara tertulis dengan lengkap.
\end{abstract}

Katakunci: Komunikasi matematika; gender; program linear.

\begin{abstract}
This study aims to describe and analyze the written mathematical communication of high school students on linear program questions based on gender. This research was conducted at SMAN 3 Pamekasan class XI MIPA I. The subjects in this study were 2 students out of 32 students of class XI MIPA I who were the superior class of mathematics selected by purposive sampling. This research uses descriptive research with a qualitative approach. The instruments used were Mathematics Ability Test, written Mathematical Communication Test and Interview Guidelines. Data were analyzed descriptively in the form of qualitative data obtained from the results of the Written Test to describe students' written mathematical communication. The results showed that female students were more dominant than male students in the cognitive domain and completed written math problems in full.
\end{abstract}

Keywords: Mathematics communication; gender; linear program

\section{Introduction}

NCTM (2000) states that there are five competencies that students must in the learning process, namely mathematical problem solving, mathematical communication, mathematical reasoning, mathematical connections, and mathematical presentations. From some of the competencies, mathematical communication skills are important and must be developed in students. Istikomah (2014) states that Mathematical communication skills can support other mathematical abilities, such as problem-solving abilities. With having good mathematical communication skills. So a problem will be represented and can be a supporter of solving problems. Mathematical communication is something that needs to be an important concern in learning mathematic (Maula,2017). Therefore mathematical communication must be own and be expanded to students in solving the problem at hand.

Communication is a form of interaction from the giver to the recipient of the message (Kluver and Kluver, 2006; Pinanti, 2014; Mulyadi, 2016). Kluver 
and Kluver (2006) state communication as a social process that regulates the rules of interaction of communicators. Communication is the process of delivering information from one person to another in the hope that the recipient of the information understands the meaning (message) of the information provider (Mulyadi, 2016). Pinanti (2014) states that communication is a process of sending and receiving messages, ideas, or ideas clearly so that the message conveyed can be digested properly by the recipient of the messaging. Communication as a process of transferring information from one person to another, the information can be understood by the recipient (Jureddi and Brahmaiah, 2016). In learning, teachers must have the best communication skills to convey learning material easily to students (Zayyadi, et al, 2019). This communication can also occur in the delivery of messages or information in solving mathematical problems.

Process communication of mathematical solving problems directly is as mathematical communication. Mathematical communication activity is like conveying problem-solving ideas, strategies, and mathematical solutions in writing or orally while Mathematical communication is a method or solution to deliver solving ideas. Mathematical communication skill is the student's skill to present the understanding that student gets and student's ideas (Mulyadi, 2016). Lesatari and Yudhanegara (2015) state that Mathematical communication skills are the ability to receive, convey ideas orally or in writing and understand the ideas or ideas of others carefully to sharpen understanding. mathematical communication skill in this study is a student's ability to absorb information in the form of symbols, pictures, objects, sounds, mathematical operations through visuals, and manage information, constructing a complete understanding or forming new ideas and then conveying mathematical information through oral, written or visual.

Mathematical communication skills can occur through spoken (vocal) and written. The Ministry of Education (in Pantaleon, et al, 2017) states that written mathematical communication skills are the ability to express ideas, understand mathematics, and realize them in written form. This written mathematical communication is important and often used in the world of education to measure students' understanding of the material that has been delivered by the teacher (Pantaleon, 2017). Wijaya, et al (2016) stated that indicators of written mathematical communication skills are 1) the ability to express mathematical ideas through writing, demonstrating, and conveying visually. 2) The ability to understand, interpret, and evaluate mathematical ideas in writing or other visual forms. 3) Ability to use written terms, mathematical notations, and structures to conveying ideas and relationships with situation models. However, the results of research conducted by Lestari (2016) show that written mathematical communication of high school students is still not able to communicate mathematics well. Written answers given by high school students in communicating mathematical ideas are still lacking (Armanto and Harahap, 2014). Therefore there is a need for further research on this matter.

Mathematical communication can occur in the problem-solving process carried out by male and female students. Gender differences affect the thinking process (Zayyadi and Maulana, 2016) and students' mathematical communication skills. Ekasari (2017) argues that women are superior to men in written mathematical communication, while men 
are superior to female subjects in oral mathematical communication. Male subjects are superior in oral mathematical communication skills, while female subjects are superior in written mathematical communication skills as well as in other visual forms (Wijaya, et al, 2016). From the explanation of the data above, it is necessary to conduct a study on the written mathematical communication skills of high school students based on gender, especially high school students.

\section{Research methods}

This research is categorized as a descriptive study with a qualitative approach (descriptive qualitative). Following the problem formulation that has been described, this study aims to describe the written mathematical communication skills of high school students based on gender differences.

The instrument in this study was the researcher himself as the main instrument in qualitative research, as well as several supporting instruments, namely the student's Mathematical Ability Test (TKM), Written Test (Written Mathematical Communication Test), and Interview Guidelines. The TKM questions used in this study were 10 questions on the SMA National Examination (UN) related to the material that has been studied by class XI students, but the UN questions given were modified into description questions. The written test (Written Mathematical Communication Test) is a test that contains linear program questions that have been prepared in advance by the researcher. The form of questions in the form of essay questions, essay questions was chosen because it can generate and develop students 'ideas and creativity in thinking so that it can be known to what extent the students' written mathematical communication skills are. However, before the written test is given, it is validated first to assess whether the written test has met the valid criteria or not.

The subjects in this study were 2 students of class XI MIPA I at SMAN 3 Pamekasan who were excellent class students. The reason for choosing class $\mathrm{XI}$ students is because they have obtained linear program material in odd semesters so that students' knowledge in the field of linear programming is sufficient to provide provisions for solving linear program problems given. This research was conducted at SMAN 3 Pamekasan because similar research has never been conducted at the school. This research will be conducted during the even semester of the 2017/2018 school year.

Data collection methods used in this study were written tests and interviews. The written test is given in the form of essay questions which consist of one linear program question that has been predetermined by the researcher. The written test is a test that has been validated by the validator team. Written tests are conducted so that researchers obtain written data about students' mathematical communication skills. Also, the results of this written test are used as a consideration for the researchers 'questions and students' answers in the interview test. Interviews in this study used a semi-structured interview method. In this semi-structured interview, the researcher refers to the interview guidelines that have been made beforehand, but if there are things that are unusual or things that need to be revealed more deeply, the researcher can ask new questions that are not in the guidelines.

After the data were obtained through written tests and interviews, data analysis was carried out with the stages proposed by Miles and Huberman (1984), namely: 1) Reduction (data reduction), 2) Display (data presentation), 3) 
Conclusion drawing/verification (concluding). In testing the validity of the data, the researcher used time triangulation, namely by checking the degree of trustworthiness of several data sources obtained at different times. Thus, data collection is carried out at least twice with different tasks but the content of these tasks is the same level. Broadly speaking, the research procedure used by the researcher consists of four stages, namely: 1) Preliminary Stage, 2) Planning Stage, 3) Implementation Stage, 4) Data Analysis Stage.

\section{Results and Discussion}

Discussion of research results is a step taken after the research data is presented and analyzed descriptively qualitatively. The discussion of the results of the presentation and analysis of the mathematics communication skills carried out is as follows. Indicators of written mathematical communication skills used in this study 1) Ability to express mathematical ideas through writing, demonstrating, and conveying them visually. 2) The ability to understand, interpret, and evaluate mathematical ideas in writing or other visual forms. 3) Ability to use written terms, mathematical notations, and structures to convey ideas and relationships with situation models.

look from the achievement of written mathematical communication indicators between male students and female students, so it can see that there are differences in the mathematical communication abilities of male subjects and female subjects as shown in table 1 below:

Table 1. Differences in ability

Subjects Male and Female

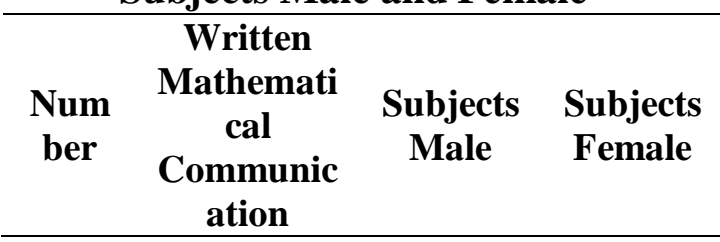

\begin{tabular}{|c|c|c|c|}
\hline & $\begin{array}{c}\text { Ability } \\
\text { Indicators }\end{array}$ & & \\
\hline 1 & $\begin{array}{l}\text { Ability to } \\
\text { express } \\
\text { mathematic } \\
\text { al ideas } \\
\text { through } \\
\text { writing, } \\
\text { demonstrat } \\
\text { e and } \\
\text { convey } \\
\text { visually }\end{array}$ & $\begin{array}{l}\text { Able to } \\
\text { sort the } \\
\text { informati } \\
\text { on in the } \\
\text { problem } \\
\text { then } \\
\text { convert } \\
\text { it into a } \\
\text { mathema } \\
\text { tical } \\
\text { sentence, } \\
\text { but the } \\
\text { subject is } \\
\text { not able } \\
\text { to } \\
\text { convey } \\
\text { his } \\
\text { mathema } \\
\text { tical } \\
\text { ideas } \\
\text { visually } \\
\text { and } \\
\text { choose a } \\
\text { solution } \\
\text { that is } \\
\text { not } \\
\text { commonl } \\
\text { y done } \\
\text { by most } \\
\text { people in } \\
\text { solving } \\
\text { problems }\end{array}$ & $\begin{array}{l}\text { Be able } \\
\text { to sort } \\
\text { the } \\
\text { informati } \\
\text { on in the } \\
\text { problem } \\
\text { then } \\
\text { convert } \\
\text { it into } \\
\text { mathema } \\
\text { tical } \\
\text { sentence } \\
\text { s, choose } \\
\text { to use } \\
\text { tables to } \\
\text { sort } \\
\text { informati } \\
\text { on and } \\
\text { use } \\
\text { solutions } \\
\text { that are } \\
\text { commonl } \\
\text { y used } \\
\text { by most } \\
\text { people to } \\
\text { solve } \\
\text { problems }\end{array}$ \\
\hline 2 & $\begin{array}{l}\text { Ability to } \\
\text { understand, } \\
\text { interpret, } \\
\text { and } \\
\text { evaluate } \\
\text { mathematic } \\
\text { al ideas in } \\
\text { writing, as } \\
\text { well as in } \\
\text { other visual } \\
\text { forms }\end{array}$ & $\begin{array}{l}\text { Able to } \\
\text { solve } \\
\text { questions } \\
\text { correctly } \\
\text { accuratel } \\
\text { y and } \\
\text { sequentia } \\
\text { lly, then } \\
\text { be able } \\
\text { to make } \\
\text { pictures } \\
\text { relevant } \\
\text { to the } \\
\text { solution } \\
\text { but not } \\
\text { able to } \\
\text { provide } \\
\text { conclusi }\end{array}$ & $\begin{array}{l}\text { Able to } \\
\text { solve } \\
\text { questions } \\
\text { correctly } \\
\text { accuratel } \\
\text { y and } \\
\text { sequentia } \\
\text { lly, then } \\
\text { be able } \\
\text { to make } \\
\text { pictures } \\
\text { that are } \\
\text { relevant } \\
\text { to the } \\
\text { solution } \\
\text { and are } \\
\text { accurate } \\
\text { in }\end{array}$ \\
\hline
\end{tabular}




\begin{tabular}{llll}
\hline & & ons & $\begin{array}{l}\text { providin } \\
\text { g } \\
\text { conclusi } \\
\text { ons }\end{array}$ \\
\hline Ability to & Able to & Able to \\
use written & use & use \\
terms, & inequalit & inequalit \\
mathematic & y & y \\
al notations & notation, & notation, \\
and & mathema & mathema \\
structures & tical & tical \\
to convey & operation & operation \\
ideas and & s, and & s, and \\
relationship & calculati & calculati \\
s with & ng & ng \\
situation & variables & variables \\
models & in & in \\
& solving & solving \\
& problems & problems \\
\hline
\end{tabular}

Based on the table, the indicators of the ability to express mathematical ideas through writing, demonstrate, and convey visually. Male subjects were able to sort out the information in the given questions. Furthermore, the subject converts it into mathematical sentences but the subject is unable to visually convey his mathematical ideas and chooses a solution that is not commonly used by most people in solving problems. Whereas the female subject was able to sort the information in the problem then convert it into math sentences, chose to use tables to sort information, and use solutions that are commonly used by most people in solving problems. The basic difference in this indicator is that the male subject is unable to convey his mathematical ideas visually and chooses a solution that is not commonly used by most people in solving problems.

On the indicators of the ability to understand, interpret, and evaluate mathematical ideas in writing, as well as in other visual forms, male subjects can solve problems correctly, precisely, and in order. Furthermore, the subject can make images that are relevant to the solution but is less able to provide conclusions. Meanwhile, female subjects were able to solve problems correctly, accurately and in order, they were able to make pictures that were relevant to the solution and were able to provide conclusions. In this case, the fundamental difference between the two subjects is in the context of providing conclusions correctly or inappropriately.

On the indicators of ability to use terms, mathematical notations, and their structures to convey ideas and relationships with situation models in writing, male subjects can use inaccuracy notation, mathematical operations, and calculating variables in solving problems. Meanwhile, female subjects can use inaccuracy notation, mathematical operations, and calculating variables in solving problems. On this indicator, the two subjects did not have differences in both male and female subjects.

Based on the above discussion, the achievement of students' written mathematical communication indicators is that male subjects are not able to convey their mathematical ideas visually and are also less able to provide a conclusion. Meanwhile, female subjects can convey visually and can provide a conclusion. So the achievement of male students' written mathematical communication is lower than female students, and this is reinforced by previous research conducted by Ekasari (2017) that female subjects are superior to male subjects in written mathematical communication, while male subjects superior to female subjects in oral mathematical communication. Male subjects are superior in oral mathematical communication skills, while female subjects are superior in written and other visual forms of mathematical communication (Wijaya, 2016; Azhari, et al, 2018). In this case, it can be said that female students are more dominant than male students in the cognitive realm and 
solve math problems in writing completely.

\section{Conclusion}

Based on the analysis of research results on research subjects, it can answer the problems that have been raised in the research problem formulation. Thus, it can be concluded that based on gender differences, the subject has written mathematical communication skills as follows: written mathematical communication skills of male subjects. The subject can sort out the information in the problem then convert it into a mathematical sentence, but the subject is unable to convey his mathematical ideas visually and chooses a solution that is not commonly done by most people in solving problems, can solve problems correctly, precisely and in order, then can make images that are relevant to the solution but are less able to provide conclusions, and can use inequality notation, mathematical operations, and calculating variables in solving problems. The written mathematical communication ability of female subjects is being able to sort the information in the problem then convert it into mathematical sentences, choosing to use tables in sorting information and using solutions that are commonly used by most people in solving problems, being able to solve problems correctly, precisely and sequentially, then being able to make images that are relevant to the solution and appropriate in providing conclusions, Able to use inequality notation, mathematical operations, and calculating variables in solving problems.

\section{References}

Azhari, D. N., Rosyana, T., \& Hendriana, H. (2018). Analisis Kemampuan Komunikasi Matematis Siswa SMP Berdasarkan Gender Dan Self Concept. JPMI (Jurnal
Pembelajaran Matematika Inovatif), 1(2),129-138.

Armanto, D., \& Harahap, M. B. (2014). Perbedaan Penerapan Model Pembelajaran Kooperatif Tipe Jigsaw dan STAD Ditinjau dari Kemampuan Penalaran dan Komunikasi Matematis Siswa SMA. Jurnal Didaktik Matematika, 1(1),113-128.

Halim, D., Nisa, S., \& Zayyadi, M. (2019). Solving Math Methods: Model Pembelajaran Berbasis Masalah Dengan Komunikasi Matematis Untuk Meningkatkan Kemampuan Berpikir. Indiktika: Jurnal Inovasi Pendidikan Matematika, 1(2),103-111.

Ekasari, D.F. (2017). Kemampuan Komunikasi Matematika Siswa Ditinjau Dari Gender kelas VII SMP NEGERI 2 Kembang Tahun Ajaran 2016/2017. Skripsi, (Eprints.ums.ac.id) diakses 14 juli 2018.

Gordah dan Astuti. (2013). Meningkatkan Kemampuan Komunikasi Matematis Mahasiswa Melalui Pengembangan Bahan Ajar Geometri Dasar Berbasis Model Reciprocal Teaching di STKIP PGRI Pontianak. Seminar Nasional Matematika Dan Pendidikan Matematika, 227- 232,

Istikomah, D.A. (2014). Upaya Meningkatkan Kemampuan Komunikasi Matematis Siswa Dengan Model Pembelajaran Kooperatif di SMPN 2 Sedayu Yogyakarta". Jurnal Pendidikan, (Online), 3(2),65-76,

Lestari dan Yudahanegara. (2015). Penelitian Pendidikan Matematika. Bandung: Refika Aditama.

Jureddi, D. N., \& Brahmaiah, N. (2016). Barriers to effective communication. Journal of English 
Language and Literature, 3(2),114115.

Lestari, D. (2016). Deskripsi Komunikasi Matematis Tertulis Pada Pembelajaran Matematika Siswa Kelas XI SMA Negeri Di Purworejo". Jurnal Pendidikan Matematika, 20(3),229-232.

Maulana, H. (2017). Studi Tentang Penerapan Teknik Bertanya Probing Terhadap Kemampuan Komunikasi Matematis Siswa Pada Pembelajaran Matematika di Kelas X.1 SMAN 1 Lubuk Sikaping". Jurnal eksakta pendidikan, 1(1),6370 ,

Mulyadi, M. (2016). Kemampuan Komunikasi Matematika Siswa Kelas VIII SMP dalam Menyelesaikan Masalah Matematika Berdasarkan Perbedaan Kemampuan Matematika. Skripsi tidak di terbitkan. Pamekasan. FKIP. Universitas Madura.

NCTM. (2000). Principles and standards for school mathematics. United State of America

Pantaleon, K.V. (2017). Profil Komunikasi Matematik Tertulis Calon Guru Matematika Dengan Tingkat Kecemasan Matematika Tinggi Dalam Pembuktian Matematik. Seminar nasional matematika dan aplikasinya. Surabaya. Universitas airlangga.

Pinanti, R.D. (2014). Kemampuan Komunikasi Matematika Siswa Dalam Pemecahan Masalah Matematika Ditinjau Dari Perbedaan Jenis Kelamin". Jurnal ilmiah pendidikan matematika, (Online), 3(3), 215-220.

Pratiwi, D. D. (2015). Analisis Kemampuan Komunikasi Matematis dalam Pemecahan Masalah Matematika Sesuai dengan Gaya Kognitif dan Gender Dona
Dinda Pratiwi. Al-Jabar: Jurnal Pendidikan Matematika, 6(2),131141.

Sugiyono. 2005. Memahami Penelitian Kualitatif. Bandung : Alfabeta.

Wijaya, dkk. (2016). Kemampuan Komunikasi Matematis Siswa Sesuai dengan Gender dalam Pemecahan Masalah Pada Materi Balok Dan Kubus (Studi Kasus Pada Siswa SMP Kelas VIII SMP Islam A-Azhar 29 Semarang. Jurnal Elektronik Pembelajaran Matematika. 4(9),778-788.

Zayyadi, M., \& Maulana, W. H. (2016). Profil Berpikir Siswa Sekolah Menengah Kejuruan Dalam Memecahkan Masalah Matematika Ditinjau Dari Gender. In Prosiding Seminar Nasional Pendidikan Matematika.

Zayyadi, M., Nusantara, T., Hidayanto, E., Sulandra, I., \& As' ari, A. R. (2019). Exploring Prospective Student Teacher's Question on Mathematics Teaching Practice. Journal of Technology and Science Education, 9(2),228-237. 